\title{
AN ELECTROCHEMICAL CELL NOISE STUDY
}

R. H. Brown, L. G. Cloud and S. J. Horn

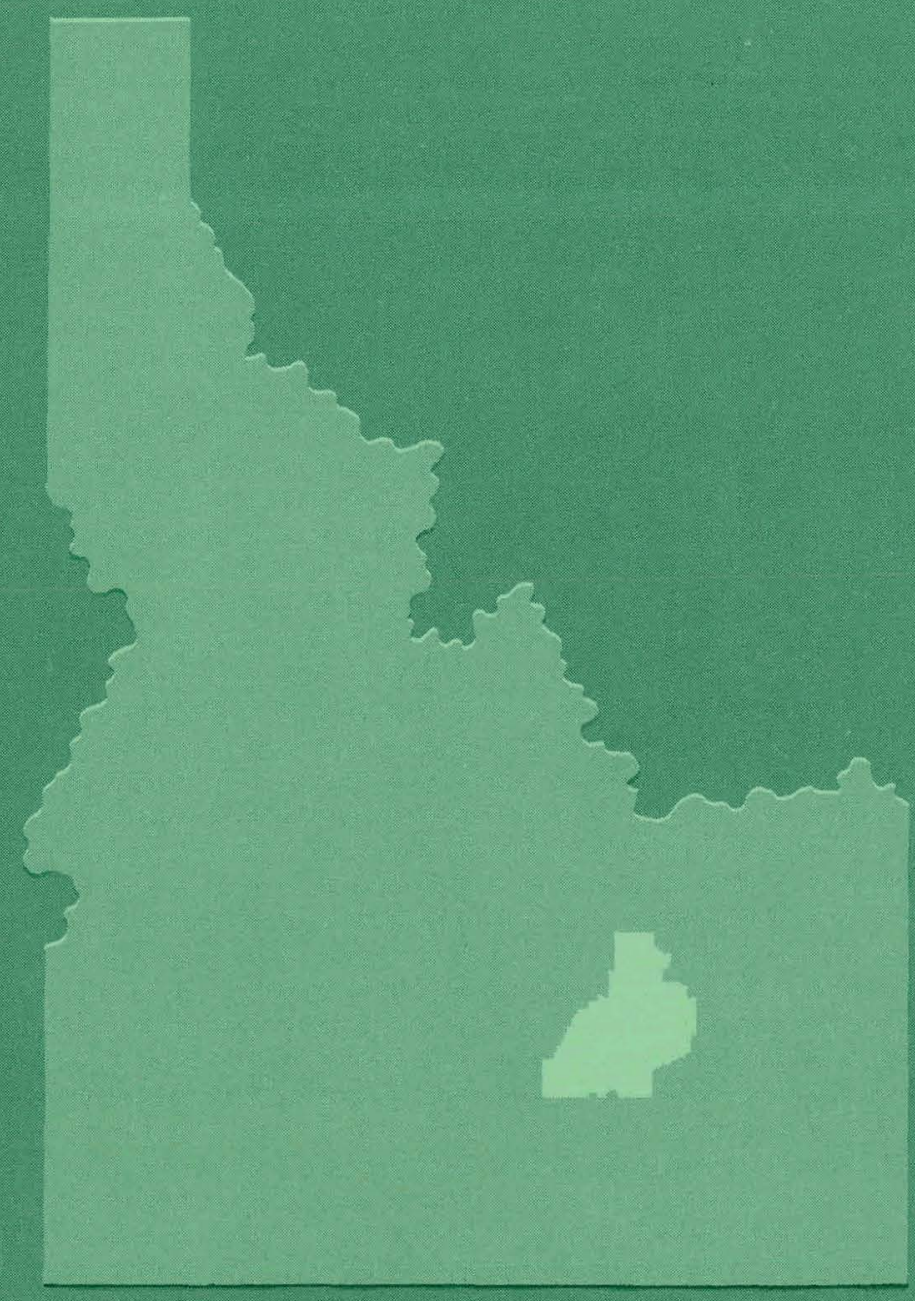

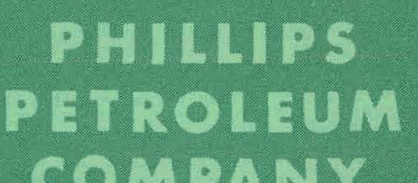
COMPANY

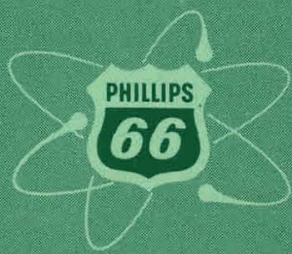

ATOMIC ENERGY DIVISION 


\section{DISCLAIMER}

This report was prepared as an account of work sponsored by an agency of the United States Government. Neither the United States Government nor any agency Thereof, nor any of their employees, makes any warranty, express or implied, or assumes any legal liability or responsibility for the accuracy, completeness, or usefulness of any information, apparatus, product, or process disclosed, or represents that its use would not infringe privately owned rights. Reference herein to any specific commercial product, process, or service by trade name, trademark, manufacturer, or otherwise does not necessarily constitute or imply its endorsement, recommendation, or favoring by the United States Government or any agency thereof. The views and opinions of authors expressed herein do not necessarily state or reflect those of the United States Government or any agency thereof. 


\section{DISCLAIMER}

Portions of this document may be illegible in electronic image products. Images are produced from the best available original document. 


\section{1,00 \\ PRICE $\$ 50^{\circ}$ \\ AVAILABLE FROM THE \\ OFFICE OF TECHNICAL SERVICES \\ U. S. DEPARTMENT OF COMMERCE \\ WASHINGTON 25, D. C.}

\section{LEGAL NOTICE}

This report was prepared as an account of Government sponsored work. Neither the United States, nor the Commission, nor any person acting on behalf of the Commission:

A. Makes any warranty or representation, express or implied, with respect to the accuracy, completeness, or usefulness of the information contained in this report, or that the use of any information, apparatus, method, or process disclosed in this report may not infringe privately owned rights; or

B. Assumes any liabilities with respect to the use of, or for damages resulting from the use of any information, apparatus, method, or process disclosed in this report.

As used in the above, "person acting on behalf of the Commission" includes any employee or contractor of the Commission, or employee of such contractor, to the extent that such employee or contractor of the Commission, or employee of such contractor prepares, disseminates, or provides access to, any information pursuant to his employment or contract with the Commission, or his employment with such contractor. 
IDO-16975

AEC Research and Development Report

Instruments

TID-4500 (30th Ed.)

Issued: June 1964

AN EIECTROCHEMICAL CELL NOISE STUDY

by

R. H. Brown, I. G. Cloud and S. J. Horn

Instrument Development

and

CPP Technical Branches

PHIIIIIPS

PETROLEUM

COMPANY

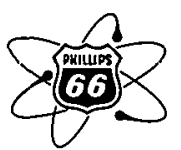

Atomic Energy Division

Contract AT(10.1)-205

Idaho Operations Office

U.S. ATOMIC ENERGY COMMISSION 


\section{ACKNNOWLEDGMENTS}

The authors wish to express their appreciation for the assistance given to them during the analysis phase of the experiment by the Instrumentation Analysis Section of the Instrument Development Branch. They also found quite helpful the cheerful cooperation of the CPP Technical Branch during the experimental phase of the project. 
AN ELECTROCHEMICAL CELL NOISE STUDY

\section{ABSTRACT}

This report describes the noise output of a bubbling electrolytic cell under various conditions of cell operation. The noise spectrum is analyzed and integrated for the purpose of providing a potentiostat noise figure. The report also indicates how a noise spectrum may be used to gain further insight into electrochemical cell mechanisms. 
AN ELECTROCHEMICAL CELU NOISE STUDY

I. INTRODUCTION . . . . . . . . . . . . . . I

A. Purpose of Report .............. I

B. Technical Background ............... 1

II. CEII NOISE MEASUREMEINT . . . . . . . . . . 4

A. Experimental Apparatus . . . . . . . . . . 4

B. Data..................... 6

III. CONCLUSIONS . . . . . . . . . . . . . . . 11

IV. REFERENCES ................... 12

FIGURES

1. Typical Electrolytic Cell . . . . . . . . . . 2

2. Potentiostat and Cell Configuration .......... 2

3. System Noise Sources . . . . . . . . . . . . 3

4. Equivalent System Noise Sources . . . . . . . . . 3

5. Diagram of Apparatus . . . . . . . . . . . . 5

6. Cell Voltage Density Output Spectrum at Total Cell

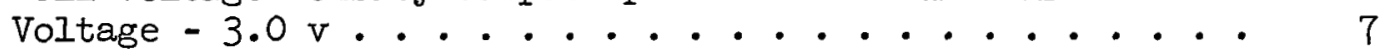

7. Cell Voltage Density Output Spectrum at Total Cell

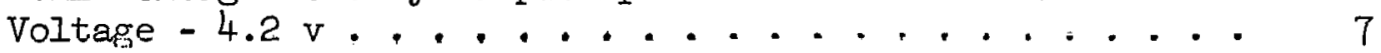

8. Cell Voltage Density Output Spectrum at Total Cell

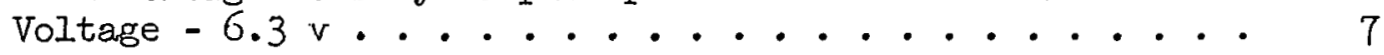

9. Chart of Cell Conditions for each Graph . . . . . . . 6

10. Electrical Analog which can produce the same spectrum as Figure 7 ................... 8

11. Simple Analog of an Electrolytic Cell . . . . . . . 9 


\section{INTRODUCTION}

\section{A. Purpose of Report}

Electrochemical research of the type performed by Dr. J. R. Aylward for CPP Technical required the development of an instrument called a Potentiostat 1 . The Instrument Development Branch provided such an instrument in 1960. At that time a noise figure was not available for an electrochemical cell and could not be obtained because the proper equipment and theoretical capability were not available at the NRTS. Since then, however, the Instrument Development Branch has developed the necessary ingredients to perform such a study. This report is an attempt to rectify the lack of information concerning electrolytic cell noise outputs. Not only will it be useful to any future potentiostat designers, but 1t also appears that cell noise studies themselves can provide information about electrochemical mechanisms that was hitherto either unavailable or obtainable only with a great deal more difficulty than with a noise study.

\section{B. Technical Background}

The type of electrochemical cell that will be considered here is a three-terminal device. It is composed of the usual two electrodes one would expect in any electrochemical device plus a third electrode or measuring electrode. The measuring electrode or "Luggin Capillary" is simply a capillary tube associated very intimately with one or the other of the two usual electrodes. The electrode associated with the Luggin Caplilary becomes the working electrode and the other is then the counter electrode. The cell is shown dlagranmatically in Figure 1. 


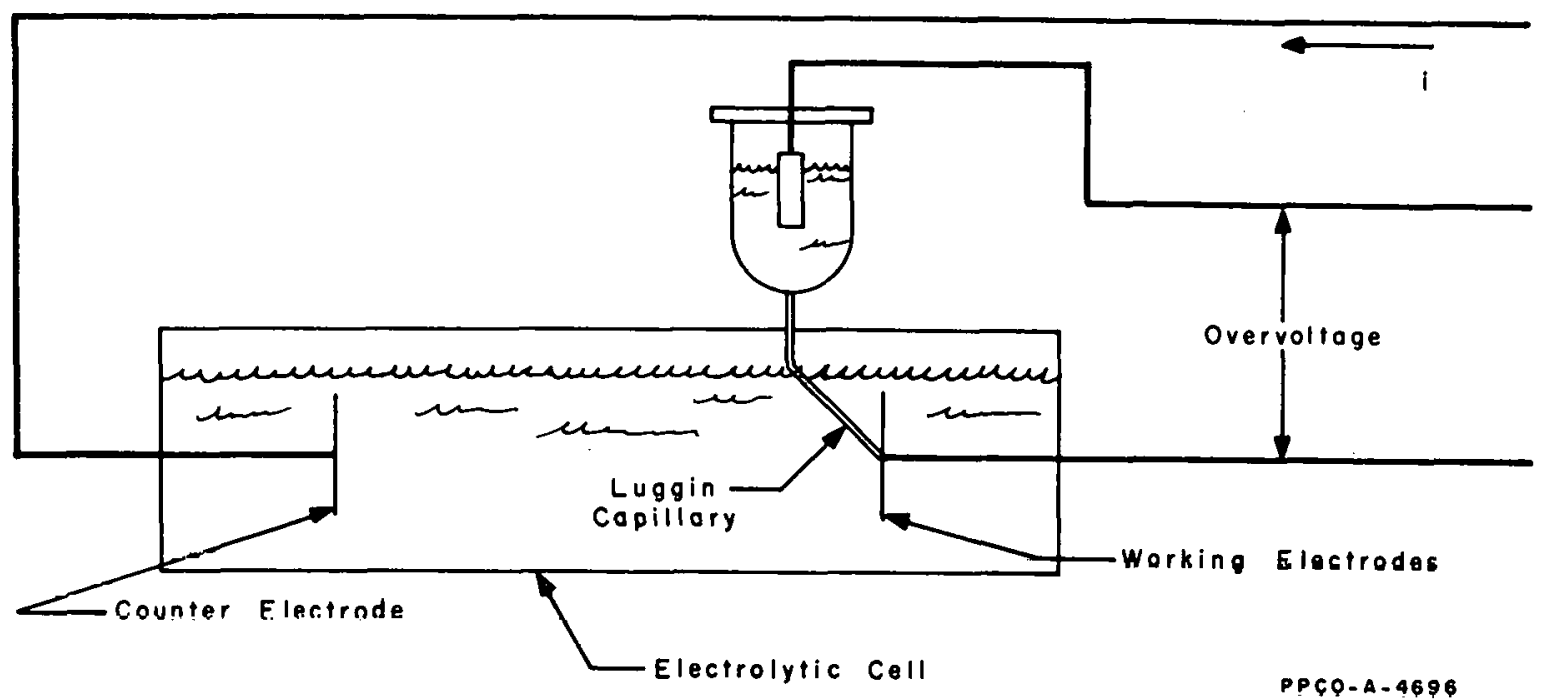

Figure 1 - Typical Electrolytic Cell

The potentiostat provides a means of holding the voltage between the Luggin Capillary and the working electrode overvoltage constant by proper manipulation of the total voltage across the cell. The potentiostat, then, is simply a power supply whose output voltage is controlled by another voltage. Figure 2 shows how the cell and the potentiostat are interconnected. It now becomes obvious why the potentiostat may not be considered separately from the ceIl and vice versa. The two together form a system which has completely different characteristics than either component alone 2 . Any study involving the noise of the system is also complicated by this fact.

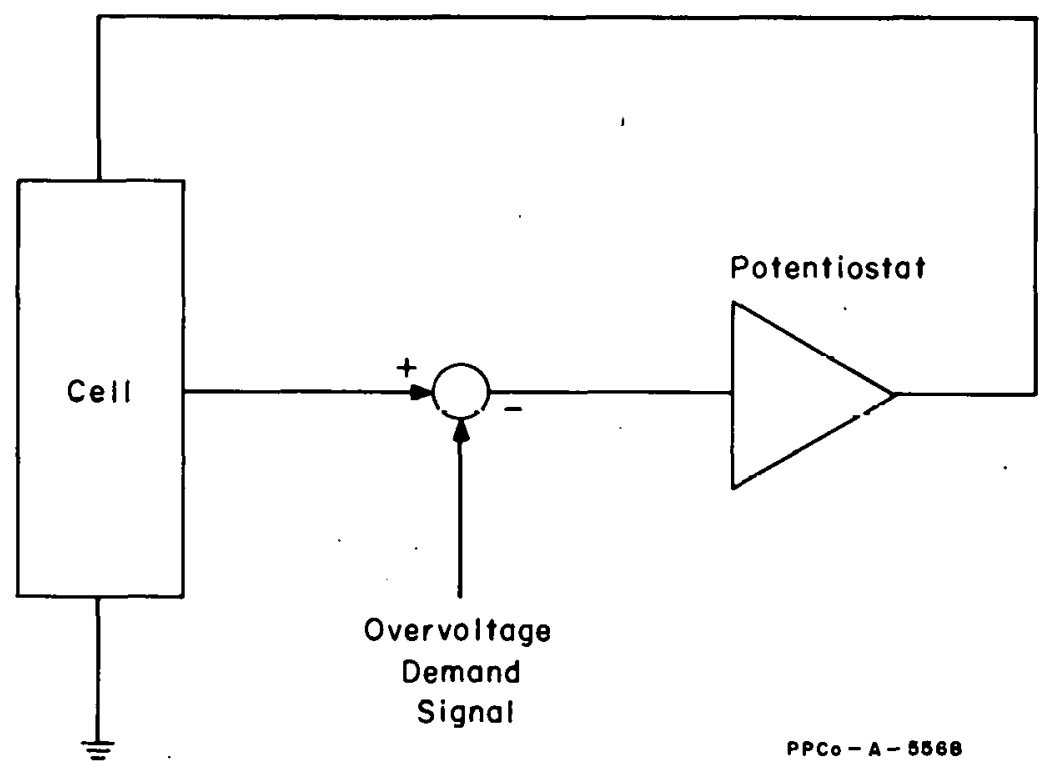

Figure 2 - Potentiostat and Cell Configuration 
In such a system as this, there are essentially two sources of noise. One source is generated by the potentiostat and the other by the cell. These are indicated in Figure 3.

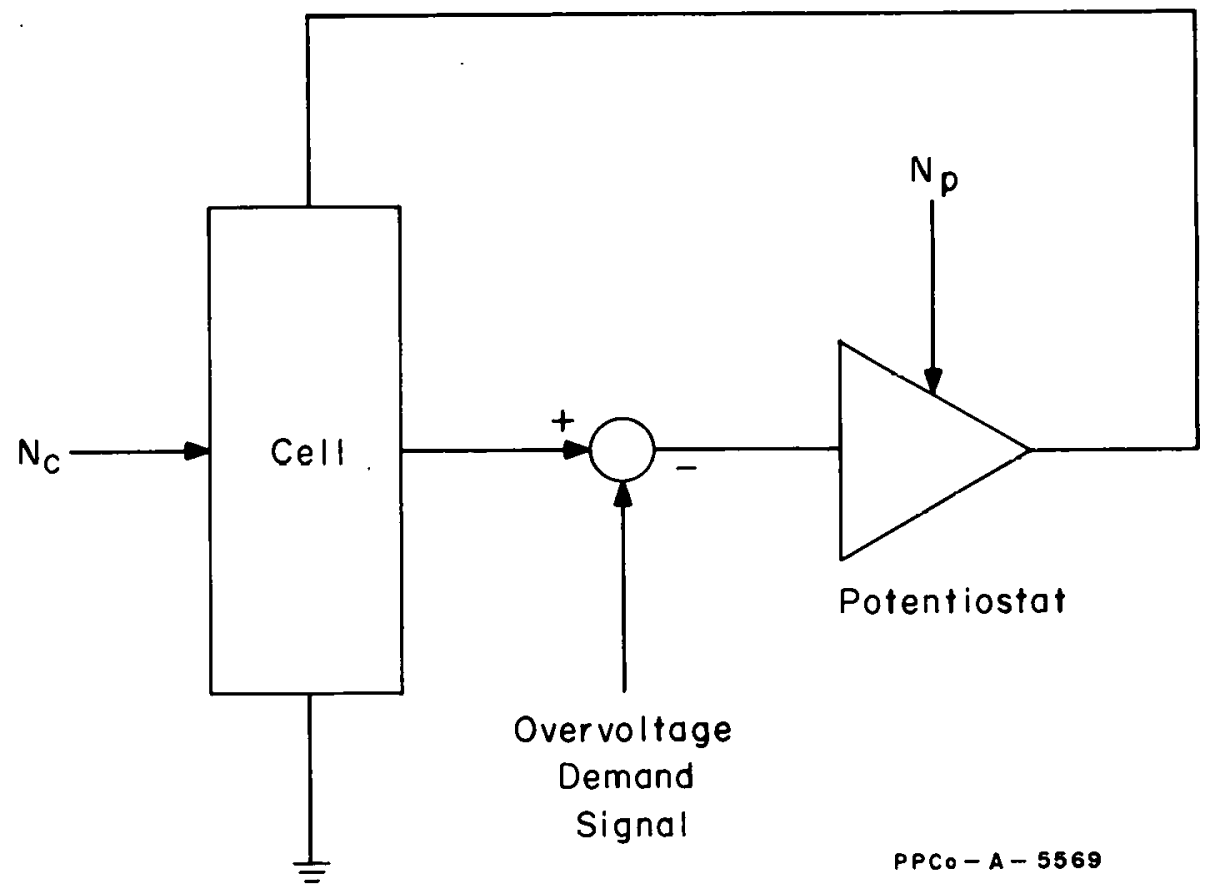

Figure 3 - Syøtem Noise Sources

In order to compare these noise sources it is convenient to refer them to the same point. Normal servomechanism theory provides the tool required to do this 3 . Standard analog computer symbolism is used to describe this situation in Figure 4.

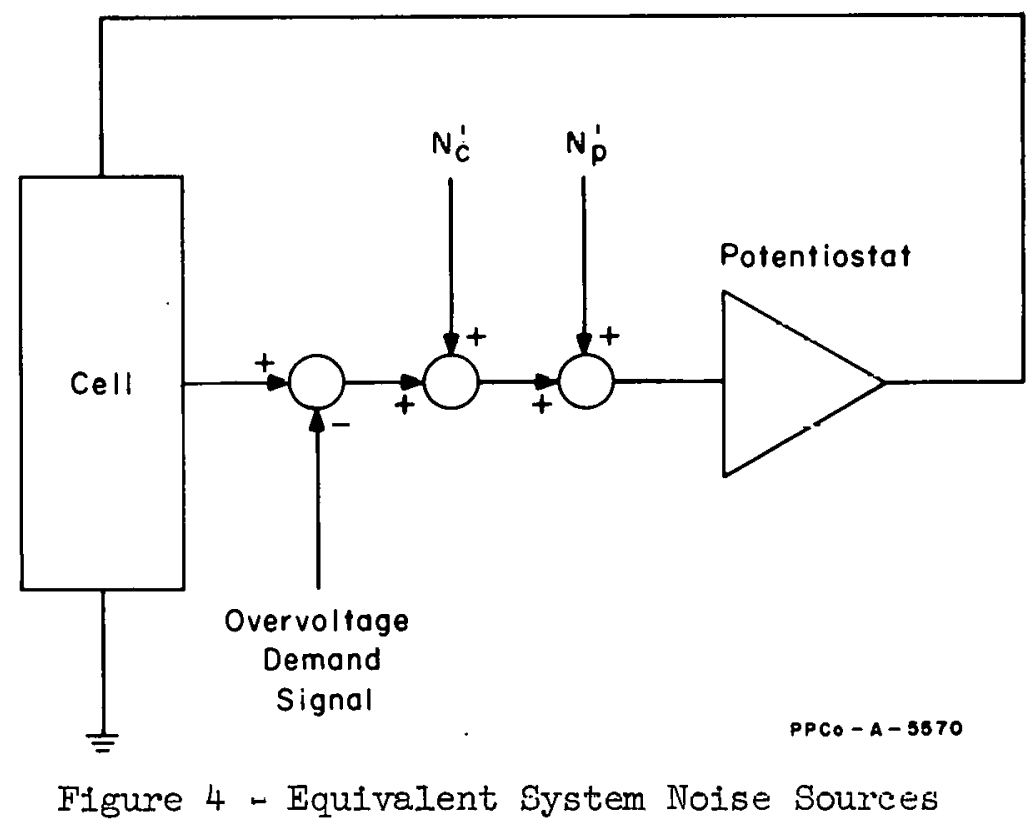


One readily sees that if the potentiostat is not to, contribute any appreciable noise to the operation of the system, $\mathrm{N}_{p}^{\prime}$ must be considerably smaller than $N_{c}^{\prime}$ at all frequencies. One might also expect $N_{c}^{\prime}$ to be minimized if the potentiostat, transfer function were developed using optimum filter noise theory 4 . In addition, a study of $\mathrm{N}_{c}$ could very well yield information concerning cell mechanisms.

Sine $N_{p}^{\prime}$ varies between potentiostats and usually can be obtained quite handily, no further discussion of it will be found in this report. our attention will henceforth be turned to a measurement of $N_{c}^{1}$.

\section{CELU NOISE MEASUREMENT}

\section{A. Experimental Apparatus}

In order to keep the noise measurement as uncomplicated as possible, the cell was connected directly across a set of storage batteries. The voltage across the cell was varied by changing connections between different types of storage batteries. Figure 5 shows the experimental apparatus with the proper interconnections.

The cell was composed of two platinum electrodes submerged in a $0.1 \mathrm{~N}$ sulphuric acid solution and spaced approximately $5.4 \mathrm{~cm}$ apart. Each electrode area was one square $\mathrm{cm}$. A saturated calomel reference electrode connected the solution in the Luggin capillary to the preamplifier. An offset voltage contained in the pre-amplifier canceled out the D.C. component of the overvoltage. No solution stirrer was used. The luggin capillary was placed as close to the working electrode as was conveniently possible.

A Sanborn Series 350-1800 stabilized D.C. pre-amplifier performed the function of raising the level of the noise signal high enough for suitable recording on a tape recorder (two volts peak-to-peak). While this pre-amplifier does not represent the ultimate in low-noise amplif'ication, it very closely approaches the state-of-the-art in such matters. Before sufficient voltage was across the cell to cause bubbling, only instrumentation noise was observed. To study mechanisms below this level (bubble formation) would require that very special low-noise amplification techniques be employed. An alternate approach to mechanism study that would emibrace this low-level problem would bc to cross correlate the output with a suitable "noisy" input.

The tape recorder was an Ampex FR-1300 operating in the FM-60 ips mode. * A 12 -minute recording was made for each set of data. The tape was then analyzed according to a scheme described elsewhere 5 and with the new Instrument Development Branch analyzer. The results from the two methods are within the experimental error as described on the data plot.

*Frequency Modulation Mode - sixty inches per second. 


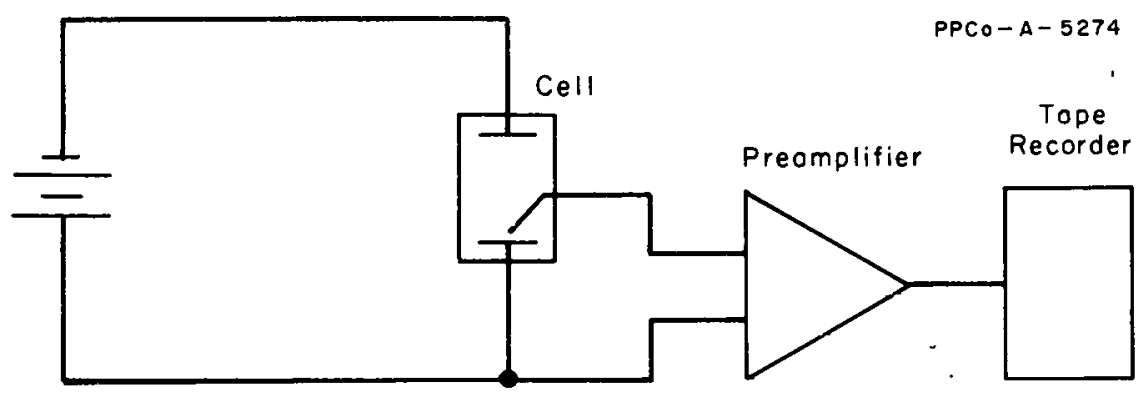

NOISE EXPERIMENT

Figure 5 - Diagram of Apparatus 


\section{B. Data}

The results of three separate measurements of cell output noise are presented graphically in Figures 6,7 and 8. A chart in Figure 9

indicates the differences between graphs.

\begin{tabular}{cccccc} 
Figure No. & $\begin{array}{c}\text { Nom. } \\
\text { Celi } \\
\text { Voltage }\end{array}$ & $\begin{array}{c}\text { Nom. } \\
\text { Celi } \\
\text { Current }\end{array}$ & $\begin{array}{c}\text { Pre- } \\
\text { Amplifier } \\
\text { Gain }\end{array}$ & $\begin{array}{c}\text { Nom. } \\
\text { Celi } \\
\text { Temperature }\end{array}$ & $\begin{array}{c}\text { Total Cell } \\
\text { Output } \\
\text { (Volts RMS) }\end{array}$ \\
\hline 6 & $3.0 \mathrm{~V}$ & $24 \mathrm{ma}$. & 1,000 & $29^{\circ} \mathrm{C}$ & $0.172 \times 10^{-3}$ \\
7 & $4.2 \mathrm{~V}$ & $53 \mathrm{ma}$. & 100 & $28^{\circ} \mathrm{C}$ & $4.1 \mathrm{x} 10^{-3}$ \\
8 & $6.3 \mathrm{~V}$ & $131 \mathrm{ma}$. & 50 & $31.5^{\circ} \mathrm{C}$ & $8.44 \times 10^{-3}$
\end{tabular}

Figure 9 - Chart of Cell Conditions for Farh Graph

Bubbling at the electrodes provided the randam noise source for the experiment. The modification of this noise by the significant parameters of the electrochemical cell produced the spectrums of Figures 6,7 and 8 . A word of caution; these particular graphs should nnt he interpreted for their electrochemical significance. They are presented only for the purpose of indicating a possible approach to such studies and to provide a noise figure for potentiostat design. For this reason no snecial attempt has been made to measure the electrochemically significant parameters with a great deal of precision. The curves will be used, however, as examples for an approach to analysis in Section III. The total cell noise output in Root Mean Square volts was obtained by integrating the voltage density spectrum. 
To illustrate how these equations might be used to gain further insight into problems of cell operation, let us assume that they are as exact as it is possible to make them. They appear below:

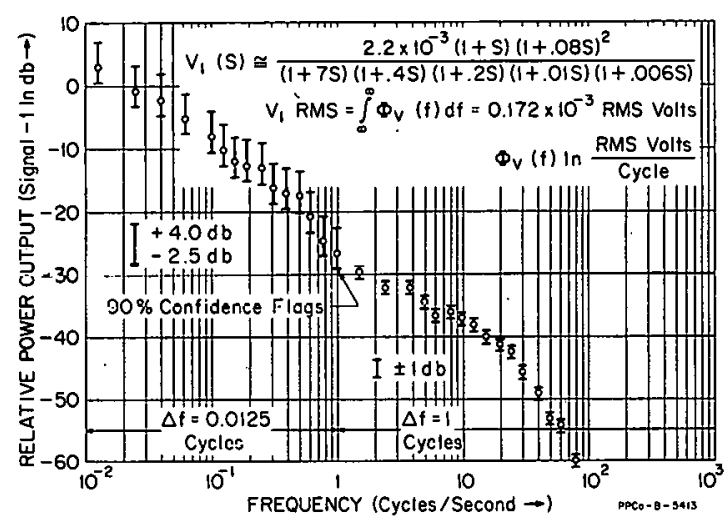

Figure 6

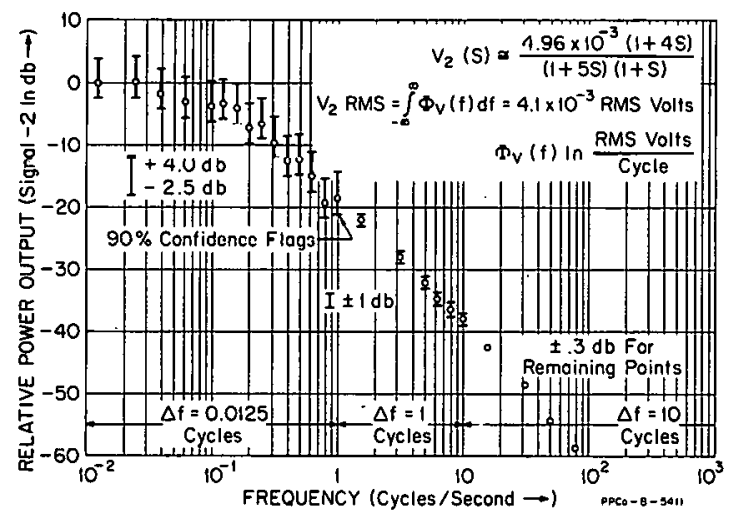

F'igure 7

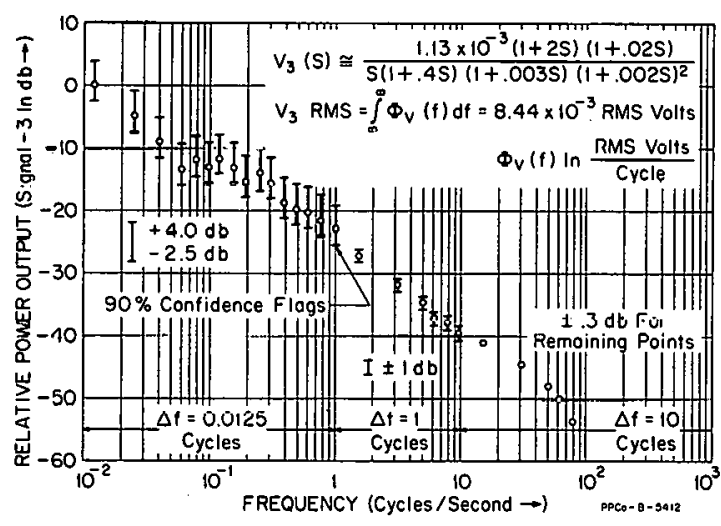

Figure 8

$$
\begin{aligned}
& V_{1}(s)= \\
& \frac{2.2 \times 10^{-3}(1+s)(1+.08 s)^{2}}{(1+7 s)(1+.4 s)(1+.2 s)(1+.01 s) \times(1+.006 s)}
\end{aligned}
$$

$V_{3}(s)=\frac{1.13 \times 1.0^{-3}(1+2 s)(1+.02 s)}{s(1+4 s)(1+.003 s)(1+.002 s)^{2}}$ 


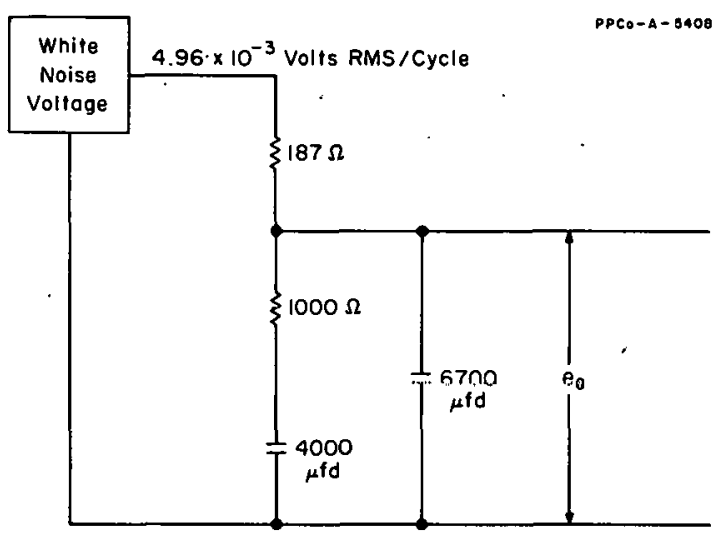

(a)

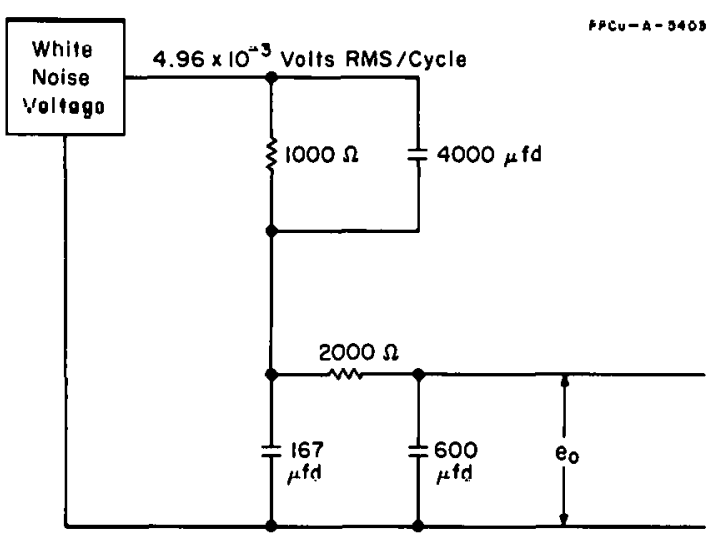

(b)

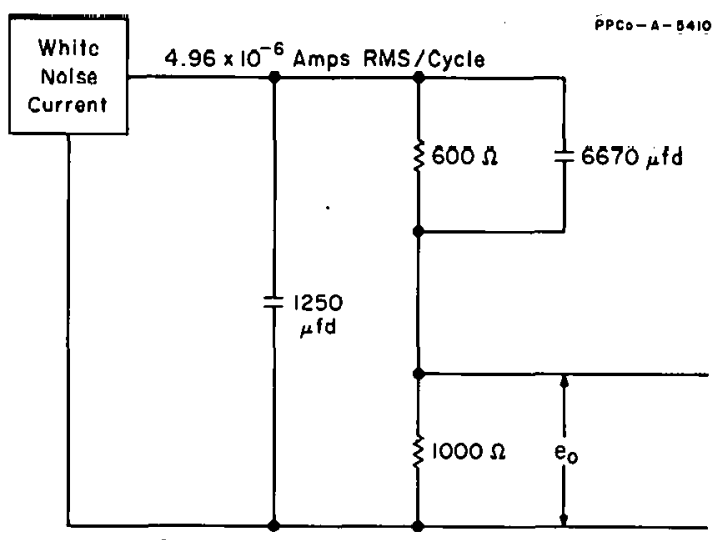

(c)

Figure 10 - Electrical analog which can produce the same spectrum as Figure 7 . where

$$
s=j \omega=j 2 \pi f
$$

and

$$
\begin{aligned}
& \omega=\text { angular frequency } \\
& j=\sqrt{-1}
\end{aligned}
$$

It is possible by means of modern electrical network theory 8 to arrive at one or more electricall analogies for each of these equations. For instance, consider the cquation of Figurc 7. Threc poooiblc electrical circuits which will produce the same output noise spectrum appear in Figure 10. By no means do they represent all the possible circuits capable of producing the same spectrum. One can expect an electochemist to be able to look at a number of such analogs for each equation and select the one which most nearly represents his concept of the particular electrolytic cell involved. Once this has been accomplished, it is a relatively simple matter to make quantitative measurements of electrochemical parameter variations as a function of different cell operating conditions.

A further example will illustrate how this method of cell study may be used to augment or replace the methods presently in use. Consider for a moment the simple $\mathrm{cell}$ analog circuit of Figure 119 . 


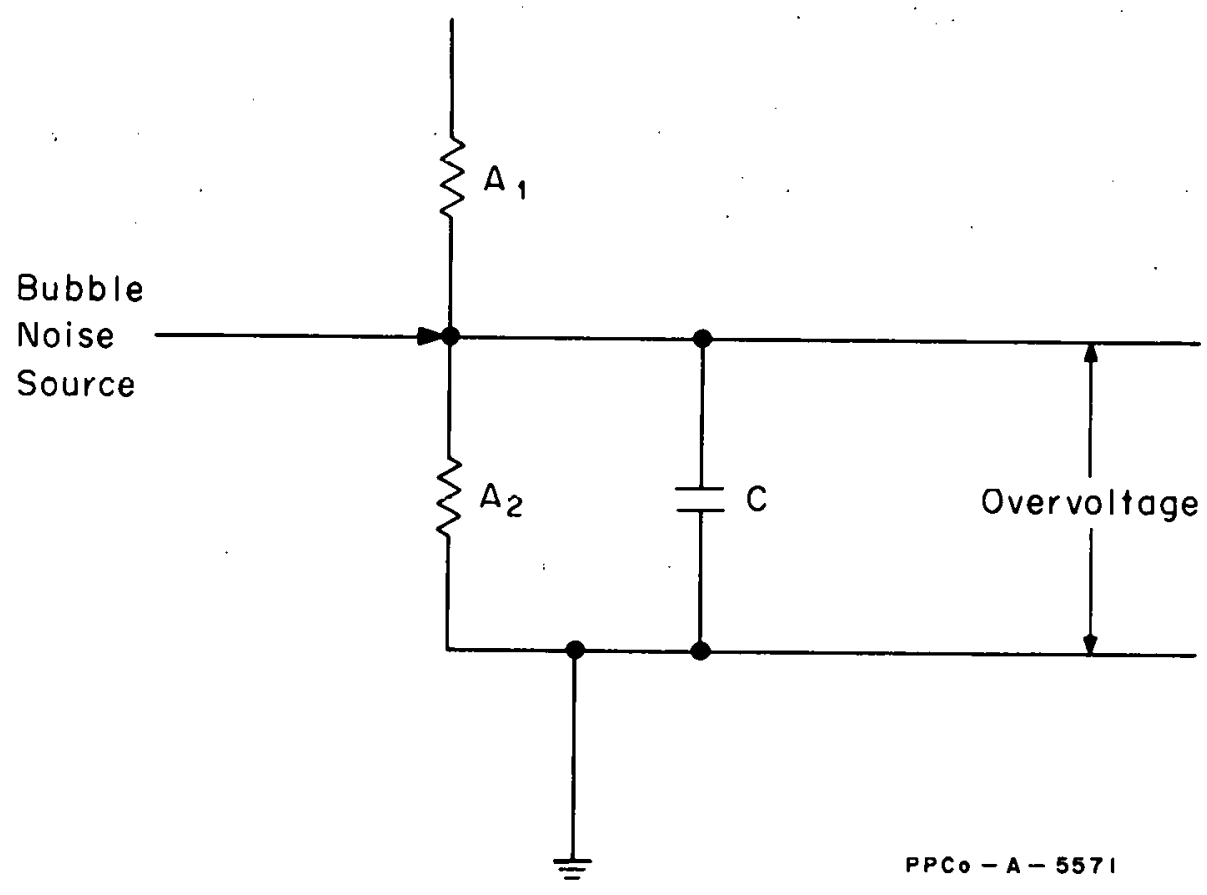

Figure 11 - Simple analog of an electrolytic ccll

$R_{I}$ is the solution resistance, $R_{2}$ the interface resistance and $C$ the double layer capacity. One of the ways of measuring $C$, of course, is to pulse the total cell voltage and measure the overvoltage vs time curve. Another way is to excite the cell with sinc wave voltages at a number of different frequencies and thus measure the cell transfer function which is dependent upon $C$. These two measurements have the disadvantage of disturbirig the cell and disallowing the use of perturbation theory to linearize the bacically non-linear alfferential equations which characterize the cell.

A third method which does not have this disadvantage because its disturbances are only the internal disturbances of the cel.t itself employs the previousiy described voltage density spectrum. The measured voltage density curve from Flgure 11 would be of the following form.

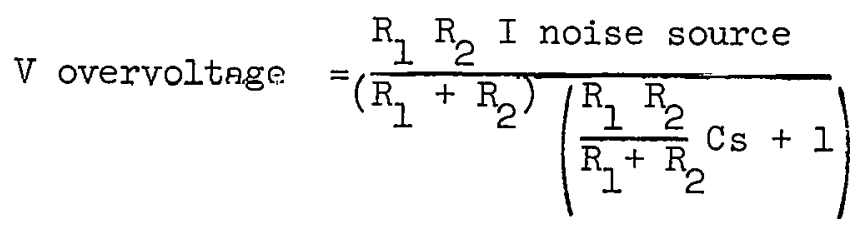


Once this form is related to the electrochemist's concept of the cell, the determination of the value of $\mathrm{C}$, the double layer capacity, is a simple matter. It, in combination with $R_{1}$ and $R_{2}$, forms the coefficient of $s$ in the noise spectrum density equation.

Similarly, one would expect the size of the double layer capacity to be involved in one of the larger coefficients of $s$ in the previous example of Figure 7. The authors feel that with more accurate data and a reasonable electrochemical concept of the cell such as identification would most certainly be possible.

Another interesting feature of the three curves involves their high frequency response. Figure 7 has a completely different high frequency response from Figures 6 and 8 , although it had a value of current density between those two. However, Figure 7 was obtained from a cell whose temperature was slightly lower than either of the other two. The dullus's would not deprive the reader of the pleasure of performing his own speculations at this point. 


\section{CONCLUSIONS}

The mathematical description of the cell noise output spectrum appears to be quite complicated. It should be noted that this mathematical description is by no means the only one capable of fitting the data within the indicated error limits. It is adequate, however, for the purpose of integration to oblain the total RMS nolse output of the cell. It quickly becomes obvious, then, that the data must have its error limits reduced by a considerable amount before any electrochemically Eignificant parameters may be studied.

Such reduction can be accomplished in a rather straight forward manner by simply taking data for a longer period of time for each cell condition. Figures 6,7 and 8 represent data taken for approximately twelve minutes for each cell condition.. The time required to obtain a given degree of precision may be readily computed from the following equation: 6

$$
\begin{aligned}
T & =\frac{K}{2 \Delta F} \\
T & =\text { time in seconds }
\end{aligned}
$$

where $\quad \Delta F=$ equivalent rectangular bandwith of filter in $\mathrm{c} / \mathrm{s}$

$$
\mathrm{K}=\text { number of degrees of freedom of a chi-squared }
$$
distribution

The number of degrees of freedom of a chi-squared distribution required to obtain a given degree of precision are available from any standarr collection ot' statistical tables $T$.

To summarize, a range of values of noise output from a bubbling electrolytic cell have been measured for a number of different current densities. These noice measurements should be of some use to those who design potentiostats. In addition to this, a new method for the investigation of electrochemical phenomena has been explored. It is the belief of the authors that this new method will prove to have much greater significance for the electrochemical world than will the particullar values obtained for the total output noise of a cell. 
IV. REFRRENCES

1. Brown, R. H., The Design of a Potentiostat for Electrochemical Research, U. S. Atamic Energy Comission, Report IDO-16852, May (1963).

2. Brown, R. H., op. cit, pp. 11-15.

3. Chesnut, H., Mayer, R. W., "Servomechanisms and Regulating System Deslyll", 1sl editiul, Vel. 1, Wilcy, New York (1951).

4. Lee, Y. W., "Statistical Theory of Communication", Ist Edition, W11ey, New Yurk. (1960). .

5. Cloud, L. G., Wilde, N., Brown, R. H., Boland, T. J., ARMF II Noise Study, U. S. Atomic Energy Cammission, Report IDO-16959 (1964).

6. Blackman, R. B., Tukey, J. W., The Measurement of Power Spectra, Dover Publications, Inc., New York (1958).

7. Hald, A., Statistical Tables and Formulas, Wiley, New York (1952).

8. Van Valkenburg, M. E., Introduction to Modern Network Synthesis, John Wiley and Sons, New York (1960).

9. Brown, R. H., op. cit., F. 4 


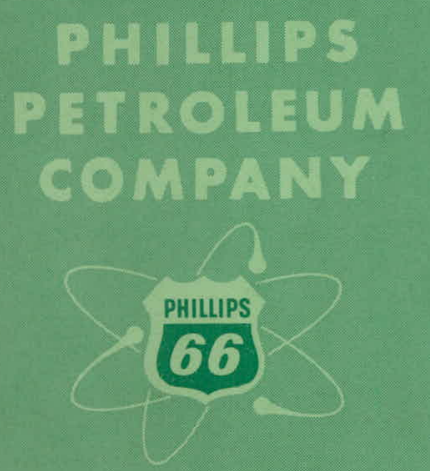

ATOMIC ENERGY DIVISION 